\title{
Bacteria in post-glacial freshwater sediments
}

\author{
Ian Miskin, ${ }^{1}+$ Glenn Rhodes, ${ }^{1,2}$ Kirsten Lawlor, $^{1} \neq$ Jon R. Saunders ${ }^{1}$ \\ and Roger W. Pickup ${ }^{2}$
}

Author for correspondence: Roger W. Pickup. Tel: +44 15394 42468/9. Fax: +44 1539446914. e-mail : roger@wpo.nerc.ac.uk

1 School of Biological Sciences, University of Liverpool, PO Box 147 Liverpool L69 7ZB, UK

2 Institute of Freshwater Ecology, Windermere Laboratory, The Ferry House, Far Sawrey, Ambleside, Cumbria LA22 OLP, UK
Prokaryote communities in post-glacial profundal freshwater sediments of Windermere, representing 10-12000 years of deposition, were examined for culturability, viability and community structure. The potential for active geochemical cycles was inferred from the presence of specific groups of bacteria. Direct count procedures revealed $10^{12}$ cells ( $g$ dry wt sediment) ${ }^{-1}$ in the surface sediments, which declined to approximately $10^{9}$ cells (g dry wt sediment) $)^{-1}$ at $6 \mathrm{~m}$ depth of core (representing approximately 10000 years of deposition). The majority of the cells in the upper sediments were metabolically active when challenged with viability probes and responded to the direct viable count method. Below $250 \mathrm{~cm}$, viability shown by 5-cyano-2,3diotyl tetrazolium chloride (CTC) dye was not significantly different from the direct count; however, counts obtained with 5-carboxyfluorescein diacetate (CFDA) and the direct viable count both declined significantly from the direct count below $250 \mathrm{~cm}$ and $1 \mathrm{~m}$, respectively. Culture was achieved from samples throughout the core, although the numbers of culturable bacteria decreased significantly with depth, from $10^{7}$ c.f.u. (g dry wt sediment) ${ }^{-1}$ to $10^{1}-10^{2}$ c.f.u. (g dry wt sediment) $)^{-1}$ below $3 \mathbf{m}$ depth. Among culturable isolates, Grampositives and Gram-negatives were found at all levels of the core, and sporeforming heterotrophs dominated. Although sulphate-reducing bacteria were not detected below $20 \mathrm{~cm}$, isolates demonstrating denitrifying activity were detected at all depths. PCR performed on samples taken below $3 \mathbf{m}$ (deposited more than $\mathbf{7 0 0 0}$ years ago) using eubacterial and archaeal primers revealed sequences similar to those found in deep sediments of the Pacific Ocean and the presence of methanogenic archaea. These observations indicate that bacteria and archaea are capable of long-term persistence and activity in deep, aged freshwater sediments.

Keywords: subsurface bacteria, freshwater sediments, survival, viability

\section{INTRODUCTION}

Sediment bacteria are acknowledged to play a critical role in benthic food webs, nutrient cycling and the

\footnotetext{
†Present address: Department of Fossil Fuels and Environmental Geochemistry, Drummond Building, University of Newcastle, Newcastle upon Tyne NE1 7RG, UK.

†Present address: Institute for Arable Research, Rothamstead Research Station, Harpenden, Hertfordshire AL5 2JQ, UK.

Abbreviations: AODC, acridine orange direct count; CFDA, 5-carboxyfluorescein diacetate; CTC, 5-cyano-2,3-diotyl tetrazolium chloride; DVC, direct viable count; MPN, most probable number; TEM, transmission electron microscopy.

The GenBank accession numbers for the sequences are given in the text.
}

decomposition of organic matter. Most research on sediment microbiology has concentrated on the upper few centimetres and the surface sediment/water interface (e.g. Jones \& Simon, 1981; Jones, 1982). However, the last decade has seen deeper sediments receiving more attention, mainly due to concerns about aquifer contamination through industrial, agricultural and other human activities (see Reeves et al., 1995; Biovin-Jahns et al., 1996; Fredrickson \& Onstott, 1996; Balkwill et al., 1997). Bacteria have now been described extensively in the subsurface environment, and have been shown to be closely involved in mineral formation and diagenic processes, some of which were initially thought to be of purely chemical origin. Bacterial activity is generally highest near the sediment surface, although there is 
indirect evidence that microbial activity continues to considerable depths within the sediment (Jones \& Simon, 1981; Jones et al., 1982; Parkes et al., 1994).

The environmental conditions that prevail within subsurface sediments are highly variable and are represented by different zones of redox potential. The type of bacterial activity varies with depth and is dependent on the zone encountered (Jones, 1985; Lovley \& Chapelle, 1995). Activities associated with carbon dioxide production, methanogenesis, denitrification, sulphate reduction, iron reduction and production of volatile fatty acids have been detected at depths down to $503 \mathrm{~m}$ in subsurface marine sediments (Ekendahl \& Pedersen, 1994; Phelps et al., 1994; Krumholz et al., 1997; Wellsbury et al., 1997). Furthermore, there are reports of the detection and/or cultivation of bacteria from sediments to depths $>500 \mathrm{~m}$ (Kennedy et al., 1994). However, aerobic organisms are most frequently studied due to ease of culture. Intact bacteria have been observed in marine sediment layers more than 4 million years old at a depth of more than $400 \mathrm{~m}$ below the sediment surface (Cragg et al., 1990, 1992; Parkes et al., 1994). Whilst direct evidence of in situ growth (dividing cells) was only reported to a depth of $10 \mathrm{~m}$ (Getliff et al., 1992), the physiological integrity of cells in deep sediments was determined by phylogenetic analysis of amplified $16 \mathrm{~S}$ rRNA genes from $500 \mathrm{~m}$ depth (Rochelle et al., 1994). Furthermore, the extraction of undegraded RNA species from a variety of sediments at depths ranging from 173 to $217 \mathrm{~m}$ (Ogram et al., 1995) implies that these bacterial communities not only persist, but maintain an in situ activity. Thus, the presence of viable bacterial populations in deep sediments has been firmly established (Balkwill et al., 1989; Chapelle \& Lovley, 1990; Hazen et al., 1991; Fredrickson et al., 1991; Parkes et al., 1994; Biovin-Jahns et al., 1996). However, the significance of the role of micro-organisms in deep sediments has not been determined.

The laminar sedimentary deposition of material in aquatic environments provides a chronological framework upon which to study the characteristics and ecology of bacteria persisting at depth. Despite increasing knowledge of subsurface environments in general, little is known about the microbiology of deep sediments underlying freshwater bodies (Rothfuss et al., 1997). Windermere, England's largest natural freshwater lake, was formed approximately 12000 years ago as the glaciers of the Late Devensian ice age receded (Pennington, 1981). The aim of this study was to investigate the persistence of bacteria deposited in the deep sediments and to provide a basic and initial description of bacterial communities in post-glacial sediments. The existing information on the paleolimnological history, including geological, climatic and anthropological effects in the late- and post-glacial sediments of Windermere, permitted the depth data to be related to the time of deposition (Macan, 1970; Pennington, 1943, 1973, 1981, 1991).

\section{METHODS}

Site description. Three intact cores $(6 \mathrm{~m})$ were recovered from the $60 \mathrm{~m}$ sampling buoy in the North Basin of Windermere in the English Lake District ( $\left.54^{\circ} 24^{\prime} 18 \cdot 6^{\prime \prime} \mathrm{N}, 002^{\circ} 57^{\prime} 24^{\prime \prime} \mathrm{W}\right)$.

Sampling. Sediment samples were recovered from an overlying water depth of $55-60 \mathrm{~m}$. Surface sediment was extracted using the Jenkin surface mud sampler (Ohnstad \& Jones, 1982) and deep sediments using the Mackereth corer (Mackereth, 1958). The sediment was processed within $3 \mathrm{~h}$ of extraction. Jenkin cores (surface to $18 \mathrm{~cm}$ depth) were sectioned according to Collins (1977). The sediment was transferred to a sterile capped $100 \mathrm{ml}$ bottle, placed on ice and processed within $1 \mathrm{~h}$. Mackereth $6 \mathrm{~m}$ sediment cores were extruded on land into four parts. As the sediment was extruded, it was immediately wrapped in sterile aluminium foil to prevent airborne contamination. Each of the four parts was then transported to the laboratory for sectioning. Internal sediment subsamples were taken at $30-40 \mathrm{~cm}$ down the core. This was achieved using sterile spatulas to remove the outer $1 \mathrm{~cm}$ of the core in one movement and in a single direction (Nilsson \& Renberg, 1990). Sediment internal to the core was then removed under aseptic conditions into a sterile capped bottle. Between each section, the sampling instruments were washed in sterile distilled water and flamed in $70 \%$ ethanol. Samples were then stored on ice and processed within $1 \mathrm{~h}$. For DNA extraction, sediment was frozen at $-70{ }^{\circ} \mathrm{C}$ as recommended by Rochelle et al. (1994).

Dissociation of cells from sediment. Filter-sterilized Windermere lakewater was used for resuspension, dilution and subsequent filtration of sediment preparations. Sediment samples were suspended in $10 \mathrm{ml}$ sterile $0.1 \%$ sodium cholate $(\mathrm{pH} \mathrm{7.3)}$ and vortexed vigorously for $2 \mathrm{~min}$ before sonication on ice for $30 \mathrm{~s}$ at $18 \mu \mathrm{m}$ amplitude. Samples were then serially diluted and total, viable and culturable bacterial numbers assessed.

Culture of environmental bacteria. A range of media was used for the isolation of bacteria from the post-glacial sediments of Windermere.

Aerobic heterotrophs. The tryptone soya agar (TSA) used comprised Tryptone Soy Broth (TSB; LabM, $50 \%$ and $5 \%$ of manufacturer's recommended strength) supplemented with agar no. 2 (LabM) to give a final strength of $1 \cdot 3 \%$. R2A agar was prepared as described by Reasoner \& Geldreich (1985). Sediment agar was prepared by adding sterile Windermere sediment (made up to $50 \%$ wet wt/volume with lakewater, autoclaved three times, each separated by $12 \mathrm{~h}$ ) to bacteriological agar $(1.5 \%)$. Bacteria isolated on these media, after incubation at $20^{\circ} \mathrm{C}$ for up to 6 weeks, were subcultured and purified on $5 \%$ TSA plates and maintained at $4{ }^{\circ} \mathrm{C}$ on $5 \%$ TSA slopes.

Sporulating bacterial populations. Aliquots $(1 \mathrm{ml})$ of samples were pasteurized at $80^{\circ} \mathrm{C}$ for $30 \mathrm{~min}$ prior to plating. Sporing aerobic heterotrophs were cultured on $50 \%$ TSA. Actinomycetes were selectively cultured on M3 agar, which was prepared using a combination of mineral salts (Rowbotham \& Cross, 1977). Throughout a 6 week period of incubation at $20^{\circ} \mathrm{C}$, the c.f.u. were counted and then the incubation temperature was elevated to $50^{\circ} \mathrm{C}$ to favour the growth of any thermoactinomycete species. Plates were re-examined for further growth. After culture, actinomycetes were identified microscopically on the basis of colonial morphology.

Anaerobic culture. Agar plates and broths, excluding the 
sulphate-reducing medium, were incubated under an anaerobic atmosphere generated by Oxoid gas-generating kits. For presumptive sporulating anaerobes, Differential Clostridial Medium (DCM; Oxoid) was used. Nutrient agar (Oxoid) was supplemented with $\mathrm{KNO}_{3}(0.1 \%)$ to determine the number of nitrate-reducing heterotrophs in sediment samples (Horsley, 1979). Plate counts were corroborated by mostprobable-number (MPN) broth counts as follows. Nutrient broth was supplemented with $\mathrm{KNO}_{3}$ to a concentration of $0.1 \%$, and $4.5 \mathrm{ml}$ aliquots were autoclaved in $13 \mathrm{~cm}$ test tubes each containing an inverted Durham tube. Five replicate serial dilutions were performed; $0.5 \mathrm{ml}$ of each diluted sample was used to inoculate the broth. Tubes were examined for growth, gas production and generation of nitrite. Reduction of nitrate was detected using the reagent of Elliot \& Porter (1971). Sulphate-reducing bacteria were enumerated by a MPN technique using Postgate medium B (Postgate, 1984) containing $20 \mathrm{mM}$ sodium acetate with a headspace mixture of $80 \% \mathrm{H}_{2} / 20 \% \mathrm{CO}_{2}$ (Jones \& Simon, 1984).

Fluorometric enumeration of bacteria. Acridine orange direct count (AODC) was performed as described by Fry (1990). Two fluorometric methods were used for viable counts. (a) The fluorescent formazan derivative CTC method of Rodriguez et al. (1992; detects respiratory activity), in which samples were diluted 1:2 with R2A broth (Reasoner \& Geldreich, 1985) and 5-cyano-2,3-diotyl tetrazolium chloride (CTC) was added to a concentration of $3.5 \mathrm{mM}$. Samples were incubated statically at $20^{\circ} \mathrm{C}$ for $4 \mathrm{~h}$. (b) Sterilized 5 -carboxyfluorescein diacetate (CFDA; detects esterase activity and denotes viability through enzyme activity and membrane integrity) was added to samples to a final concentration of $0.01 \mathrm{mM}$. Samples were statically incubated for $10 \mathrm{~min}$ at $20^{\circ} \mathrm{C}$ followed by $15 \mathrm{~min}$ on ice. In both cases, the sample was filtered through a $0.22 \mu \mathrm{m}$ black membrane and then stored in the dark before counting within $20 \mathrm{~min}$. Negative controls comprised samples that were autoclaved or treated with membrane-filtered formaldehyde (to a final concentration of $4 \%$ for $1 \mathrm{~h}$ before incubation). Direct viable count (DVC) was done by a modification of the method of Kogure et al. (1987). Filter-sterilized piromidic acid, pipemidic acid and nalidixic acid were added to cultures to final concentrations of 10,10 and $20 \mu \mathrm{g} \mathrm{ml} \mathrm{m}^{-1}$, respectively, then incubated at $20^{\circ} \mathrm{C}$ for $16-18 \mathrm{~h}$ with shaking. After incubation, samples were immediately stained with CTC and the numbers of bacterial cells counted by microscopy. Negative controls comprised samples treated with membrane-filtered formaldehyde (to a final concentration of $4 \%$ for $1 \mathrm{~h}$ before incubation).

Microscopic counting strategy. For AODC, DVC, CTC and CFDA counts, stained cells were visualized with a Zeiss Axioplan fluorescence microscope using appropriate optical filters. Triplicate filters were wet mounted in low-fluorescence immersion oil (Leica) and counted within 20 min of staining. Counts were made in accordance with the recommendations of Fry (1990). Bacteria were assumed to be Poisson distributed; 40 randomly chosen microscope fields (or enough to count 400 bacteria) were scanned per filter, and bacteria-like objects counted. Only samples diluted $>3000$-fold, visualized within fields containing $\leqslant 50 \%$ particulate obstruction, were counted; no correction of counts for particulate obstruction was performed.

Transmission electron microscopy (TEM). Electron microscopy was carried out on deep sediment samples using a JOEL 100CX Temscan electron microscope. Previously frozen sediment $\left(-70^{\circ} \mathrm{C}\right)$ was allowed to thaw, and 2.5 microlitres of the melt water was removed and spotted directly on to a copper electron microscopy grid. Four grids were prepared for each subsection examined. All grids were osmium tetroxide fixed; two from each section were shadowed with chromium, and subjected to TEM at various magnifications.

Direct extraction of DNA from sediment. This method was derived from those of Selenska \& Klingmuller (1991), Rochelle et al. (1992) and Smalla et al. (1993). Sediment samples (5 g wet wt sediment) were vortexed in $10 \mathrm{ml}$ extraction buffer $[0 \cdot 12 \mathrm{M}$ sodium phosphate buffer, $\mathrm{pH} 8 \cdot 0$; lysozyme, $5 \mathrm{mg}$ $\mathrm{ml}^{-1}$; sodium dodecyl sulphate, $1.5 \%$; acid-washed polyvinylpolypyrrolidone (PVPP; $6 \%$ )], sonicated at $18 \mu \mathrm{m}$ amplitude for $20 \mathrm{~s}$ on ice and then incubated for $1 \mathrm{~h}$ at $70^{\circ} \mathrm{C}$ with frequent shaking. Following this, the samples were centrifuged at $2800 \mathrm{~g}, 4{ }^{\circ} \mathrm{C}$ for $15 \mathrm{~min}$, and the supernatant was retained at $4{ }^{\circ} \mathrm{C}$. This procedure was repeated twice without further addition of PVPP. The pooled supernatants were then centrifuged at $8000 \mathrm{~g}, 4{ }^{\circ} \mathrm{C}$ for $30 \mathrm{~min}$. Proteins were precipitated from the final supernatant by the addition of $0 \cdot 1 \mathrm{vol} .5 \mathrm{M}$ $\mathrm{NaCl}$ and polyethylene glycol 6000 (to a final concentration of $15 \%$ ) and overnight incubation at $4{ }^{\circ} \mathrm{C}$ followed by centrifugation $\left(5000 \mathrm{~g}, 4^{\circ} \mathrm{C}\right.$ for $\left.40 \mathrm{~min}\right)$. The pellet was resuspended and purified following ethanol precipitation (Sambrook et al., 1989).

PCR amplification. The PCR was carried out using a Perkin Elmer Cetus 480 thermal cycler and performed using primers $\mathrm{pA}, \mathrm{pD}^{\prime}$ and $\mathrm{pH}^{\prime}$, specific to the eubacterial $16 \mathrm{~S}$ rRNA gene (Edwards et al., 1989), and 1Af and 1100Ar, specific to the archaeal 16S rRNA gene (Embley et al., 1992). Prior to 'hot start', samples were serially diluted tenfold to achieve the optimal sample concentration for amplification. Template DNA was added to a standard PCR reaction mix, giving a total volume of $45 \mu \mathrm{l}$, comprising $20 \mathrm{pmol}$ of each primer, $10 \mathrm{nmol}$ of each deoxynucleoside triphosphate (Pharmacia), PCR buffer [50 mM KCl, $10 \mathrm{mM}$ Tris/ $\mathrm{HCl}(\mathrm{pH} 8 \cdot 3), 1.5 \mathrm{mM}$ $\mathrm{MgCl}_{2}$; Boehringer Mannheim]. Reactions were overlaid with $50 \mu \mathrm{l}$ liquid paraffin $(\mathrm{BDH})$ in thin-walled $\mathrm{PCR}$ reaction tubes (Anachem). The amplification reaction comprised an initial cycle of denaturation at $95^{\circ} \mathrm{C}$ for 4 min followed by addition of $5 \mu \mathrm{l} 1 \times$ PCR reaction buffer containing 0.5 U Taq DNA polymerase (Boehringer Mannheim) and $1 \mathrm{U}$ Perfect Match polymerase enhancer (Stratagene) at $80^{\circ} \mathrm{C}$. This was followed by 30 cycles of denaturation at $95^{\circ} \mathrm{C}$ for $1 \mathrm{~min}$, annealing for $1 \mathrm{~min}$ at $55^{\circ} \mathrm{C}$ and extension at $72^{\circ} \mathrm{C}$ for $2 \mathrm{~min}$ with a final extension step of $72^{\circ} \mathrm{C}$ for $10 \mathrm{~min}$.

Cloning of PCR products. PCR products were ligated into the cloning vector pCRII provided in the TA-Cloning Kit (Invitrogen), following the manufacturer's instructions. Recombinant plasmids were used to transform $50 \mu \mathrm{l}$ TA One Shot Competent Cells by the manufacturer's specified protocol. Transformants were plated on selective agar containing X-Gal (Boehringer Mannheim), subcultured and screened for the presence of an appropriate insert by plasmid minipreparation-restriction analysis using the method of Close \& Rodriguez (1982).

Sequencing. Plasmid DNA was extracted from clones using Qiaprep Spin columns (Qiagen). Cloned genes were sequenced using T7 polymerase (Pharmacia). Electrophoresis and reading of the sequences were performed on an automated laser fluorescence ABI 373A DNA sequencer (ALF; Pharmacia). The GenBank accession numbers for the sequences are: Wineub 010, AF045172; Wineub 012, AF045175; Wineub 019, AF045176; Wineub 027, AF045170; Wineub 043, AF045168; Wineub 076, AF045171; Wineub 082, AF045169; Wineub 115, AF045173; Wineub 117, AF045174; Winarc 007, AF045181; 
Winarc 031, AF045178; Winarc 041, AF045179; Winarc 045, AF045180; Winarc 150, AF045177.

Analysis of DNA sequence data. Sequences were analysed using the GCG suite of programs (Devereux et al., 1984) running on the SEQNET Facility at Daresbury (UK). Sequences were visually aligned with representative sequences from National Science Foundation Ribosomal Database Project (RDP; Larsen et al., 1993) and the GenBank Database (Benson et al., 1993) on SEQNET. Only unambiguously aligned base positions were used in the analysis. Analyses and measures of robustness were corroborated by DNADIST (PHYLIP version 3.5) using the Jukes \& Cantor (1969) correction. Phylogenetic trees were constructed by the neighbour-joining method (Saitou \& Nei, 1987). Bootstrap analysis was performed using SEQBOOT (PHYLIP 3.4) to evaluate the robustness of the inferred phenograms and CONSENSE (PHYLIP 3.4) (Felsenstein, 1993) was used to generate a consensus phenogram in conjunction with the 'neighbour-joining method'. Topology of phenograms was confirmed by maximum parsimony analysis.

Statistical analyses. The following analyses were performed where appropriate: MPN (Halvorsen \& Zeigler, 1933); analysis of variance (probability of $0.01 \%$; Fry, 1993); MINITAB 8.21, Minitab, State College, PA, USA]; minimum significant difference (MSD, Tukey-Kramer method; Fry, 1993).

\section{RESULTS}

\section{Intercomparability of cores}

Visual examination of the varve stratification confirmed that the cores taken on the three occasions were representative of a typical vertical section of the sediment (Collins, 1977; Haworth, 1985). The data are derived from three separate $6 \mathrm{~m}$ Mackereth cores taken in the late spring/summer over a period of 15 months. The initial bacteriological survey compared direct, viable and culturable counts at different depths spanning the complete core $(40 \mathrm{~cm}$ to $6 \mathrm{~m})$. All three cores were comparable with respect to stratigraphy, culturable aerobic heterotrophic counts and AODC $(P<0.05$; data not presented). Data for the top $30 \mathrm{~cm}$ were derived from independent Jenkin cores from the same sample point. Measurements of carbon, nitrogen and water content confirmed those made by Pennington (1973), giving further confirmation of core comparability (data not shown).

\section{Microscopic examination of the cores}

Electron microscopy. The nature of the sediment prevented TEM procedures that employed resin embedding and sectioning. However, it was possible to visualize cells after freeze/thawing the samples and placing them directly on electron microscopy grids. A range of bacterial morphologies was observed by TEM at depths down to $2 \cdot 3 \mathrm{~m}$. Rod-shaped bacteria were observed in sediment from subsections $0.1 \mathrm{~m}, 1.5 \mathrm{~m}$ and $2.3 \mathrm{~m}$. The dimensions of these ranged from $1.8 \times 0.3 \mu \mathrm{m}$ to $3.8 \times$ $0.5 \mu \mathrm{m}$ (Fig. 1a). In the case of the rod-shaped bacterium from $2.3 \mathrm{~m}$ (approximate size $1.5 \times 0.5 \mu \mathrm{m}$ ), intracellular structures were visible (Fig. 1b). Coccoid bacteria undergoing division, ranging in diameter from $0 \cdot 2$ to $0.3 \mu \mathrm{m}$, were observed in subsections $0.12 \mathrm{~m}$ and $1.5 \mathrm{~m}$ (Fig. 1c, d). Bacteria with apparent prosthecate structures were observed at $2 \cdot 3 \mathrm{~m}$, with prostheca lengths between 4 and $12 \mu \mathrm{m}$ (data not presented). No stalk bands were observed along the length of the prostheca in any of the cases. The viability of these organisms could not be determined at this stage.

Direct count. AODC was used to visualize and enumerate bacteria present in the sediment. In general, the bacteria observed were small and rounded when viewed in situ. The majority of cells stained green rather than orange with acridine orange and $>90 \%$ remained particleassociated. No numerical correction was made to account for bacteria beneath particles; therefore the counts were consistent, but may underestimate cell numbers. Microcolonies were observed, although infrequently, in all organic sections examined. Filamentous bacteria were observed only in the top $10 \mathrm{~cm}$ of the sediments and similarly no protozoa were observed in subsurface samples below a depth of $10 \mathrm{~cm}$. Total counts were approximately $10^{\mathbf{1 2}}$ cells ( $\mathrm{g}$ dry wt sediment) ${ }^{-1}$ for the surface sediments (Jenkin core), then declined significantly within the subsurface sediments, but remained consistent from a depth of $0.9 \mathrm{~m}$ to $4.0 \mathrm{~m}$ at $3 \cdot 7-7 \cdot 3 \times 10^{9}$ cells ( $\mathrm{g}$ dry wt sediment) ${ }^{-1}$, at which point a significant $(P<0.01)$ drop to $<10^{8}$ (g dry wt sediment $)^{-1}$ occurred that was coincident with an increasing clay content of the sediments (Fig. 2a, b).

Viable count. The number of metabolically active bacteria was assessed by the application of CTC and CFDA as fluorogenic viability dyes (Fig. 2a, b). In addition, the DVC assay method of Kogure et al. (1987) was used to enumerate bacteria capable of demonstrating growth (Fig. 2b). CTC- and CFDA-fluorescent cells were easily distinguishable, with minimal non-specific staining occurring. Control samples, obtained by formaldehyde treatment and autoclaving, generated no visible fluorescence.

There was no significant difference between the number of CTC-reducing cells and the AODC throughout the depth of the core $(P<0.01$; Fig. $2 a)$. By contrast, the CFDA-cleaving populations were high in upper sediments, being equivalent to total and CTC-reducing populations to a depth of $250 \mathrm{~cm}(P<0.01)$; thereafter, numbers decreased consistently and significantly from the AODC values with depth $(P<0 \cdot 01)$. The relationship between AODC and CTC-reducing cells was confirmed in the analysis of a later core complemented with bacterial enumeration from section of a surface Jenkin core $(0-20 \mathrm{~cm}$; Fig. 2b). AODC decreased rapidly with depth from a surface maximum of $1.48 \times 10^{12}$ ( $\mathrm{g}$ dry wt sediment $)^{-1}$ to approximately $4.45 \times 10^{9}$ (g dry wt sediment $)^{-1}$ at $74 \mathrm{~cm}$ depth; thereafter, populations remained approximately constant in size (Fig. 2b). CTCreducing populations again were not significantly different from the total populations $(P<0.01)$.

The viability of these metabolically active populations 

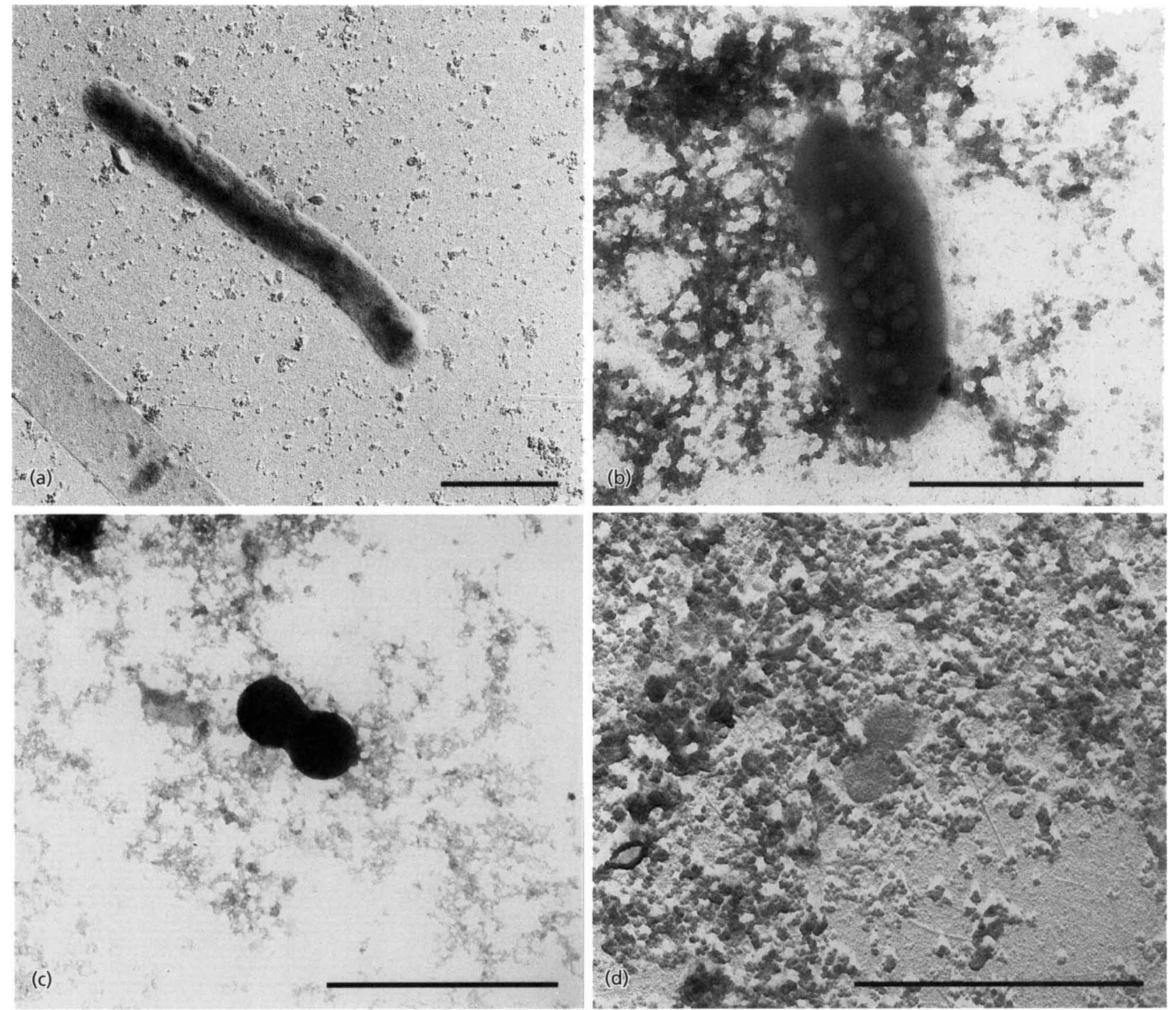

Fig. 1. TEM micrographs of chromium-shadowed bacteria: (a) rod-shaped bacterium recovered from $1.5 \mathrm{~m}$ ( $\sim 2800$ years deposition); (b) rod-shaped bacterium recovered from $2.3 \mathrm{~m}$ ( $\sim 4250$ years deposition), showing unidentified intracellular structures; (c) coccoid bacterium from $0.1 \mathrm{~m}$ ( $\sim 37$ years deposition); (d) sample from $1.5 \mathrm{~m}$ ( 2800 years deposition) showing cells fixed at the time of apparent cell division. Bars, $1 \mu \mathrm{m}$.

was investigated further by an adaptation of the DVC assay using CTC as the resolving fluorochrome (Fig. 2b). A $16-18 \mathrm{~h}$ incubation was performed in the presence of yeast extract and a cocktail of antibiotics inhibitory to cell division (Kogure et al., 1987). The total number of CTC-reducing cells decreased in all samples after incubation. However, cells capable of growth under these incubation conditions were clearly distinguishable as elongated rods. The number of substrate-responsive cells remained proportional to the pre-incubation AODC and CTC-reducing counts; cells demonstrating growth following incubation decreased rapidly in number with depth from the surface sediments until a depth of about $1 \mathrm{~m}$. Thereafter, the population size remained approximately consistent with depth to $400 \mathrm{~cm}$, below which numbers again declined through to the deepest sampling point (Fig. 2a, b).

\section{Culturable bacteria and fungi}

Aerobic culture. In a preliminary study, aerobic heterotrophs from all depths of a $6 \mathrm{~m}$ core were recovered by spreading on R2A agar and TSA at $50 \%$ and $5 \%$ strength (Fig. 3a). The number of culturable heterotrophic bacteria decreased significantly within the first metre $(P<0.01)$, from a surface value of $2 \cdot 1 \times 10^{7}$ cells $(\mathrm{g}$ dry wt sediment) $)^{-1}$ (not shown on graph) and continued to decline to approximately $10^{3}$ cells (g dry wt sediment $)^{-1}$ at a depth of $3 \mathrm{~m}$. Below this depth, the culturable population declined slowly and was main- 


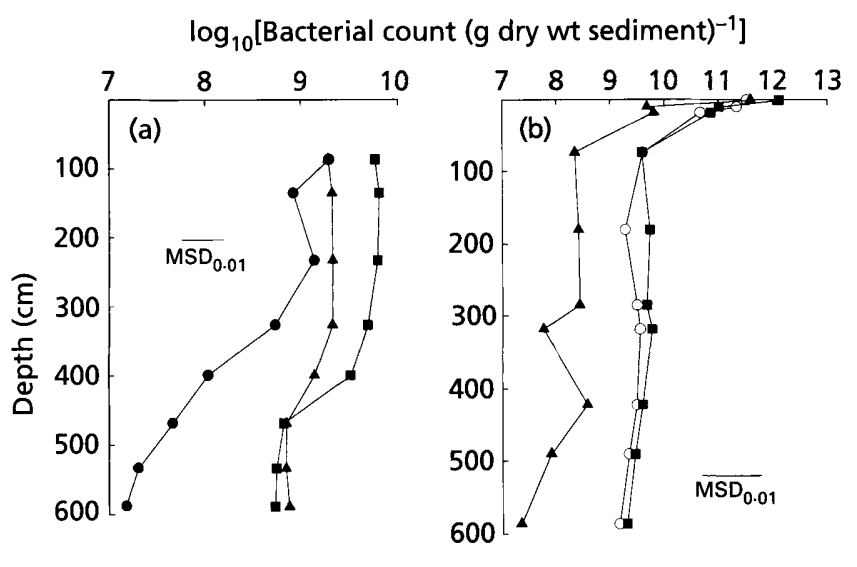

Fig. 2. (a) Depth distribution of total bacteria using the AODC technique ( $\square$ ), and of metabolically active bacteria using CTC (A) and CFDA (O) to $587 \mathrm{~cm}$ depth. (b) Depth distribution of total bacteria using the AODC technique $(\boldsymbol{D})$ and the DVC viability assay. CTC-reducing cells were enumerated to indicate total viability $(0)$. Substrate-responsive CTC-reducing cells (direct count; $\boldsymbol{\Lambda}$ ) became classically elongated. The MSD $_{0.01}$ bars indicate the mean significant difference $(P<0.01)$.

tained at a low level $\left[10^{1}-10^{2}\right.$ c.f.u. (g dry wt sediment $)^{-1}$ ] by $6 \mathrm{~m}$. Regardless of the sedimentary horizon sampled, no significant difference in culture efficiency was observed between the aerobic heterotroph media $(P<0 \cdot 01$; Fig. 3a). The exception was sediment agar, which recovered significantly lower numbers (data not presented). Low numbers of fungi and yeast were distributed throughout the sediments with no perceivable pattern. Colonies were selected arbitrarily from each medium at all depths and purified on the medium from which they were originally isolated. As these sediments were anoxic, the anaerobic growth capability of the isolates was tested. Isolates were subcultured on to nutrient agar supplemented with $0 \cdot 1 \% \mathrm{KNO}_{3}$ and plates were incubated anaerobically under $\mathrm{N}_{2} / \mathrm{CO}_{2} / \mathrm{H}_{2}$ $(85: 10: 5)$ for 2 weeks at $20^{\circ} \mathrm{C}$. It was found that $98 \%$ $(n=150)$ of isolates were facultatively anaerobic.

Bacterial isolates were crudely classified as rods, cocci and branched chains by microscopy; $>95 \%$ of the isolates were rods, with equal numbers of cocci and branched chains. Gram-staining was ambiguous for approximately $45 \%$ of the isolates. To a depth of $2 \mathrm{~m}$, Gram-negative organisms were twice as abundant as Gram-positive ones, whereas below this depth Grampositive and Gram-negative organisms were in equal proportions. It should be noted, however, that the gross numbers recovered below $2 \mathrm{~m}$ were reduced.

The presence of sporing bacteria was assessed. Surface sediments contained greater numbers of total culturable cells than sporing ones $(P<0 \cdot 01)$. However, in subsurface samples there was no difference between the heat-resistant and heat-sensitive populations (Fig. 3b). The single exception was the deepest sample $(5.9 \mathrm{~m})$, where recovery was significantly higher after heat
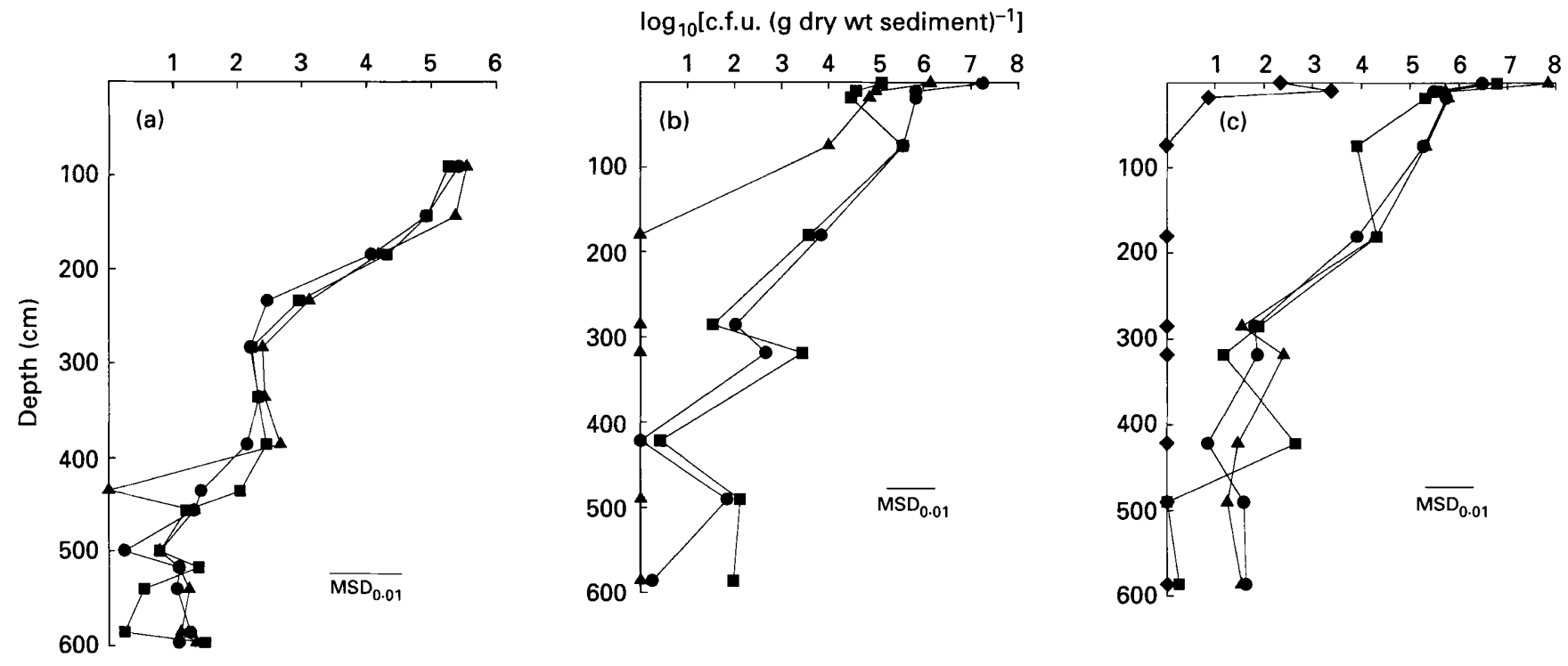

Fig. 3. (a) Depth distribution of aerobic heterotrophic bacteria isolated on R2A agar (A), $50 \%$ TSA ( $\boldsymbol{(})$ and $5 \%$ TSA (Q). The $\mathrm{MSD}_{0.01}$ bar indicates the mean significant difference $(P<0.01)$. (b) Distribution of bacteria recalcitrant to pasteurization at $80^{\circ} \mathrm{C}$. To select actinomycetes, samples were treated for $10 \mathrm{~min}$ before plating on $\mathrm{M} 3$ medium (A). For aerobic heterotrophic bacteria, samples were plated on $50 \%$ TSA before $(\boldsymbol{O})$ and after $(\boldsymbol{\square}) 30 \mathrm{~min}$ pasteurization. The $M_{0.01}$ bar indicates the mean significant difference $(P<0.01)$ (MSD value calculated upon data from TSA plates only). (c) Distribution of anaerobic heterotrophic bacteria isolated on Differential Clostridial Medium (DCM; $D$ ) and nitrate agar $(\bullet)$. Sulphate-reducing $(\bullet)$ and nitrate-reducing $(\boldsymbol{\Delta})$ populations were also enumerated by MPN broth culture. The MSD $_{0.01}$ bar indicates the mean significant difference $(P<0.01)$ (MSD value calculated upon data from the DCM and nitrate agars only). 


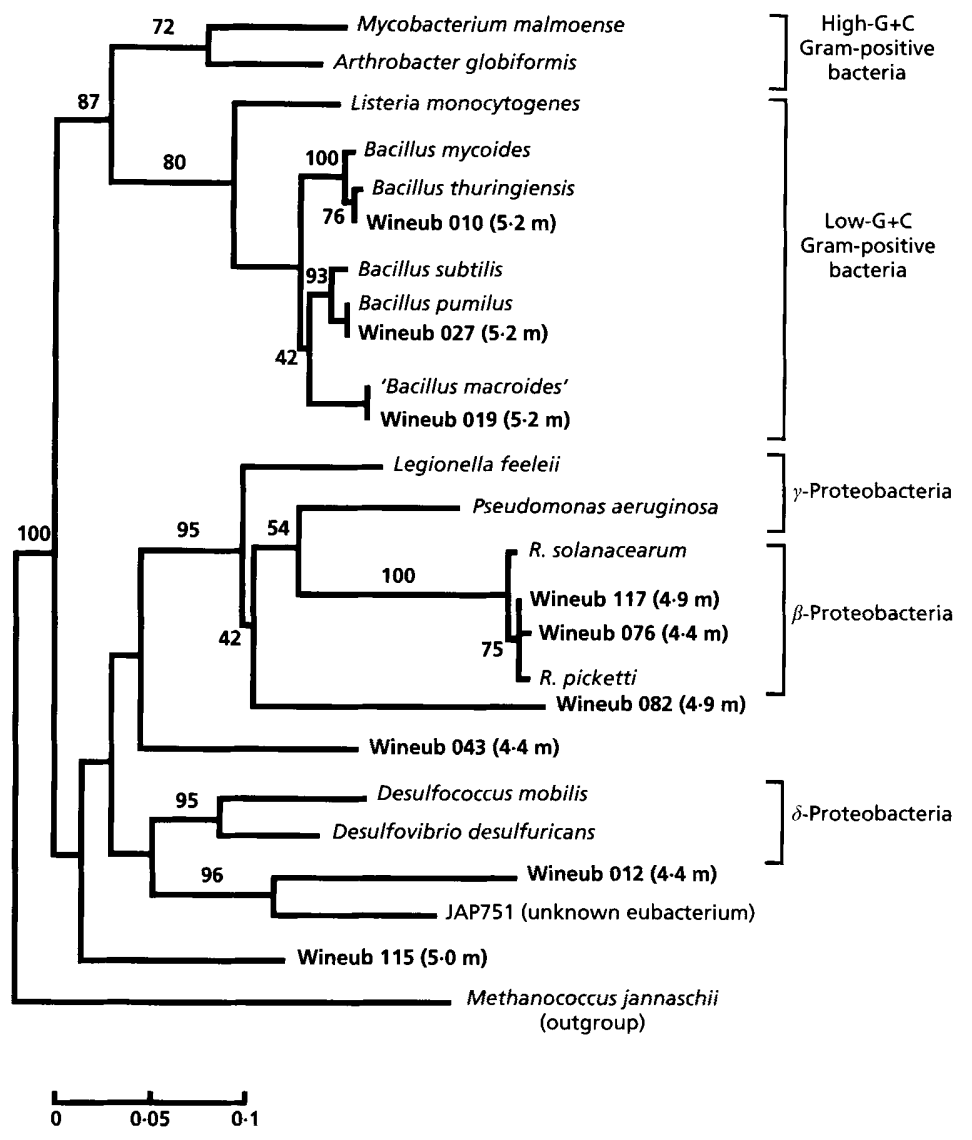

\begin{abstract}
Fig. 4. Phylogenetic relationships of eubacterial 165 rRNA gene sequences isolated from Windermere subsurface sediments (prefix Wineub). The depth from which the clones were obtained is shown in parentheses. Data for reference strains were obtained from GenBank or RDP (Larsen et al., 1993). R., Ralstonia (formerly Burkholderia). Base positions 107-180 and 220-316 were considered in the analysis (numbering based on E. coli; Brosius et al., 1978). Methanococcus janaschii was used as the outgroup. Bootstrap values were derived from 100 analyses; only values greater than $40 \%$ are shown at nodes. The scale bar represents base changes per nucleotide position.
\end{abstract}

treatment $(P<0 \cdot 01)$. This strongly suggests that all culturable bacteria below $30 \mathrm{~cm}$ are spore-formers. Actinomycete populations consisted of only Micromonospora sp., identified on the basis of its highly characteristic colony morphology (Cross, 1981). Maximum concentrations were recovered from the surface sediments $\left.\left[1.65 \times 10^{6} \text { (g dry wt sediment }\right)^{-1}\right]$, with the number of isolates decreasing rapidly with depth; no actinomycetes were recovered below a depth of $74 \mathrm{~cm}$ (Fig. 3b).

Anaerobic culture studies. A variety of culture media were utilized to assess the sedimentary bacterial populations capable of anaerobic growth. Spread-plate and MPN broth methods detected denitrifying populations. Neither technique was found to be significantly more sensitive $(P<0.01$; Fig. 3c). Denitrifying heterotrophs were cultured from all depths, with maximal populations recovered from surface sediments $\left[3.46 \times 10^{6}\right.$ c.f.u. (g dry wt sediment) $\left.{ }^{-1}\right]$. Culturable anaerobic heterotrophs were recovered at a frequency indistinguishable from that of the aerobic heterotrophs throughout the length of the core, dropping by approximately 5 orders of magnitude over the entire depth $(P<0.01)$ and being finally maintained at $10^{2}$ c.f.u. (g dry wt sediment) ${ }^{-1}$ below $3 \mathrm{~m}$.

Sporing anaerobic isolates were recovered from all samples. The pattern of culturability was comparable to that of the aerobic and anaerobic heterotrophs down to $4 \mathrm{~m}$. Below this point the sporing anaerobes declined further, to $<10^{1}$ c.f.u. (g dry wt sediment) ${ }^{-1}$. By contrast, sulphate-reducing bacteria were cultured only in the three uppermost samples : $2.5 \times 10^{2}$ c.f.u. (g dry wt sediment $)^{-1}$ in the surface sediments, approximately $10^{3}$ c.f.u. (g dry wt sediment) ${ }^{-1}$ at a depth of $10 \mathrm{~cm}$ before declining to 8.4 c.f.u. (g dry wt sediment) ${ }^{-1}$ at $18 \mathrm{~cm}$; Fig. 3(c).

\section{Extraction of DNA from core samples}

Total DNA was extracted directly from all 14 subsections. AODC indicated that the lysis efficiency of the prokaryotic population was approximately $98 \%$. DNA recovered was of a suitable purity, when diluted to $10^{-2}$ and $10^{-3}$, to act as template for amplification by PCR. PCR amplification was carried out using both eubacterial and archaeal $16 \mathrm{~S}$ rRNA primers.

\section{Eubacterial 16S rDNA amplification}

A region of approximately $1.5 \mathrm{~kb}$ of the eubacterial $16 \mathrm{~S}$ rRNA gene using the primer pair $\mathrm{pA} / \mathrm{pH}^{\prime}$ was successfully amplified from all samples (Edwards et al., 1989). These amplicons were confirmed as eubacterial $r r n$ genes by hybridization with digoxigenin-labelled eub338 probe (data not presented). In addition, as amplification and cloning procedures are more efficient with smaller products, amplification of a 528 bp region of the $r r n$ gene was performed on selected samples $(0.9 \mathrm{~m}$ to $5.2 \mathrm{~m})$ using the primer pair $\mathrm{pA} / \mathrm{pD}^{\prime}$ (Edwards 


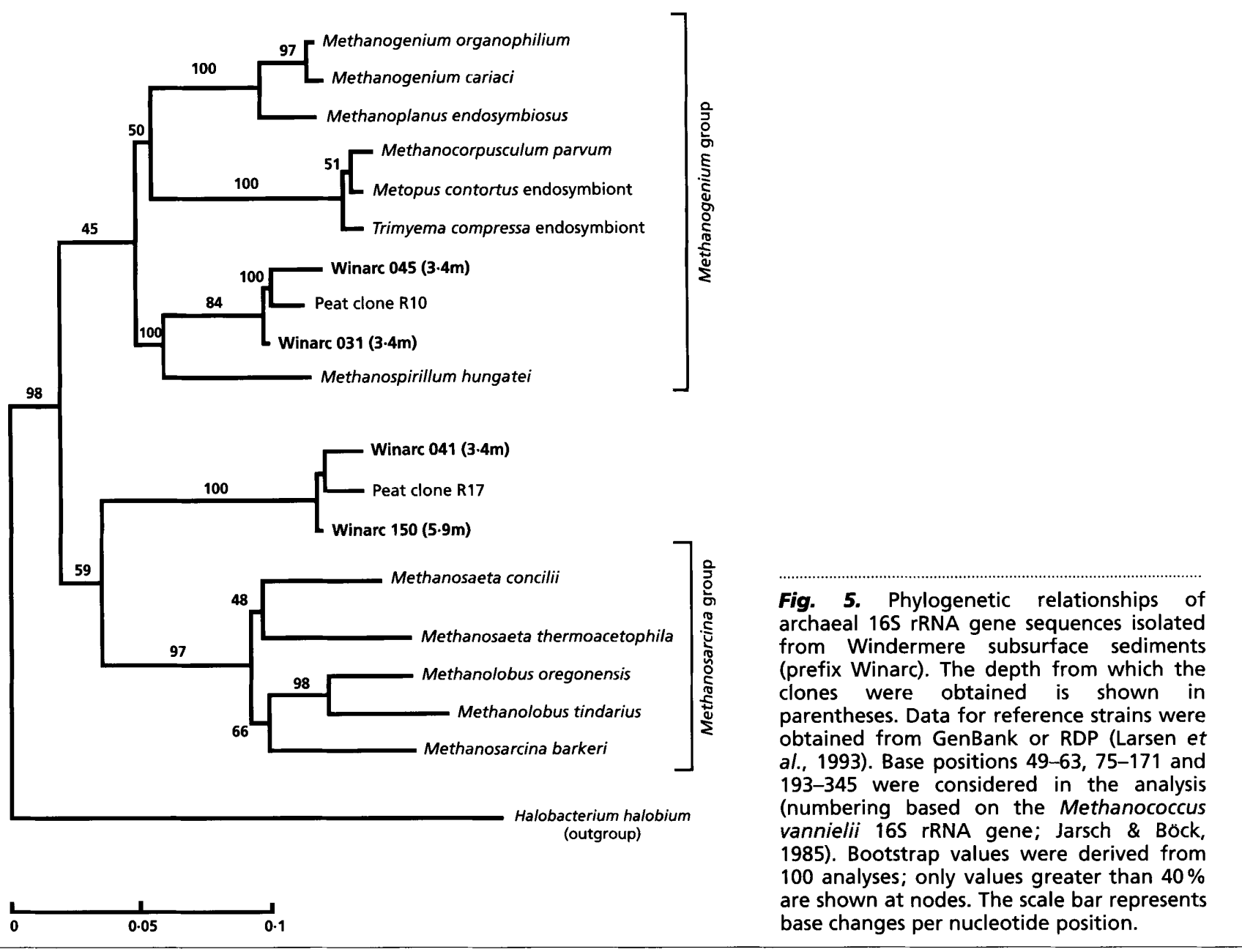

et al., 1989). Fourteen eubacterial 16S rDNA gene sequences, generated by both $\mathrm{pA} / \mathrm{pH}^{\prime}$ and $\mathrm{pA} / \mathrm{pD}^{\prime}$, were analysed from the deeper samples. Five of the sequences were found to be homologous to each other: Wineub 049/076 $\left(\mathrm{pA} / \mathrm{pD}^{\prime}\right)$, Wineub $117\left(\mathrm{pA} / \mathrm{pH}^{\prime}\right)$ and Wineub $063 / 065\left(\mathrm{pA} / \mathrm{pD}^{\prime}\right)$ were isolated from depths of $4.4,5.0$ and $5.2 \mathrm{~m}$, respectively, using the primers indicated in parentheses.

Of the 14 cloned sequences, Wineub 010, 012, 019, 027, 076,082 and 117 were found to be $>90 \%$ homologous to previously described $16 \mathrm{~S}$ rDNA sequences available in GenBank. Two major sequence groups were apparent (Fig. 4). The clones Wineub 010, 019 and 027 clustered within the low-G +C Gram-positive bacteria $(100 \%$ confidence value from 100 analyses) and all were very closely related to Bacillus sp. Clones Wineub 076, 082 and 117 grouped within the $\beta$-Proteobacteria, with the closest relative for Wineub 076 and 117 being Ralstonia (formerly Burkbolderia) pickettii (bootstrap value $75 \%$; Fig. 4). Wineub 082 and 043, by contrast, represent a distantly branched novel lineage within the Proteobacteria. The same comparison positioned Wineub 012 and 115 outside the Proteobacteria. However, further phylogenetic assessment of Wineub 012 showed it to have the greatest homology with JAP751 from the
JAP504 cluster (bootstrap value $96 \%$; Fig. 4), originally described by Rochelle et al. (1994).

\section{Archaeal 165 rDNA amplification}

The primers 1Af and 1100Ar (Embley et al., 1992) were used to amplify a $1 \cdot 1 \mathrm{~kb}$ region of $16 \mathrm{~S}$ rDNA specific to archaea. Products were obtained from all samples except $5.0 \mathrm{~m}$ and $6.0 \mathrm{~m}$; this result was attributed to sample failure rather than indicating the absence of an archaeal community at these points.

Nine archaeal $16 \mathrm{~S}$ rDNA clones were isolated from $3 \cdot 4$ and $5.9 \mathrm{~m}$ depth. They were of two general types, each showing highest identity to $16 \mathrm{~S}$ rDNA sequences isolated from uncultured archaeal populations of the subsurface blanket bog peat of the Pennine high moors (UK) (Hales et al., 1996). A $350 \mathrm{bp}$ region of the $1100 \mathrm{bp}$ sequence of the nine archaeal clones was found to represent four different sequence types. Two, represented by Winarc 045 and Winarc 031, clustered with R10, the predominant methanogen sequence type found in Cumbrian blanket bog peat (Hales et al., 1996; bootstrap value $84 \%$; Fig. 5). The two other sequence types, represented by Winarc 041 and 150, grouped with R17 (bootstrap value $100 \%$ ), a minority sequence type found 
in Cumbrian blanket bog peat (Hales et al., 1996). On the basis of distance matrix analysis, the R10-like sequences grouped within the Methanogenium group, with close association to Methanospirillum hungatei (bootstrap value $45 \%$ ). R17-like sequences were placed closer to the Methanosarcina group, the confidence of this placement being similarly low (bootstrap value $59 \%$ ).

Sequences of the R10 group gave high homologies to the $16 \mathrm{~S}$ rRNA genes from the endosymbiotic bacteria of the anaerobic protozoa Trimyema compressa and Metopus contortus, which are closely related to, but distinct from, the free-living methanogens (Fig. 5). No protozoa were observed throughout the extensive microscopic examination of the prokaryotic populations of these sediments. Indeed, there have been no reports of their isolation from these, or other, lacustrine subsurface sediments of Cumbria. However, the possibility that protozoal cysts present in the sediments may, after lysis, serve as a source of archaeal template could not be discounted due to possible presence of archaeal endosymbionts (Embley et al., 1992). For this reason, PCR amplification of protozoan small-subunit $18 \mathrm{~S}$ rRNA ( $1.7 \mathrm{~kb}$ ) was attempted using the primers of Embley et al. (1992); however, no products were obtained.

\section{DISCUSSION}

A study on sediments in Lake Constance showed that viable counts and potential activities exhibited by bacteria were a function of depth (Rothfuss et al., 1997). It was shown for post-glacial sediments (down to a depth of $7 \mathrm{~m}$ and equivalent to 13000 years of deposition) that non-sporing heterotrophs were not present below $25 \mathrm{~cm}$ and that viable bacteria belonging to specific metabolic groups were present only down to $50 \mathrm{~cm}$. Below this depth, viable heterotrophic bacteria existed only as heat-resistant spores, falling below the detection limit at $4-6 \mathrm{~m}$. We present evidence, obtained through electron microscopy, culture, and cellular and molecular analyses, that post-glacial sediments of Windermere, dating from approximately 12000 years ago to the present day, contain viable bacterial populations comprising mainly sporing bacteria. Both the direct counts and total culturable heterotrophic bacteria recovered demonstrated an exponential decrease in numbers from the surface to a depth of approximately $0.8 \mathrm{~m}$ (1200 years). The culturable count then showed a slower decline to $3.0 \mathrm{~m}$ (4000 years); thereafter, numbers remained at a constant level. The paleolimnological history of Windermere has been studied extensively (Pennington, 1943, 1973, 1981, 1991) and those studies have shown that that the composition of the sediment down to $0.8 \mathrm{~m}$ could have been influenced by extensive deforestation occurring in the catchment through early settlements (Vikings) to the extensive habitation of the present day (Pennington, 1991). The main effect of deforestation was to increase the input of sediment, with a subsequent reduction in lake volume. This is consistent with a rise in both organic carbon and phosphate in the sediments. The discontinuities in direct and culturable counts around $0.8 \mathrm{~m}$ depth may, therefore, be related to anthropological influences initiated around this period of time (approximately 1500 years deposition). The second but less defined discontinuity in culturable count at $3.0 \mathrm{~m}$ occurred in sediments of high organic content influenced by a period of climatic cooling and increased water run-off from the catchment.

In this study, pasteurization of samples prior to plating indicated that the majority of culturable aerobic bacteria were capable of sporulation. Whether the cells isolated were resuscitated from a state of dormancy cannot be determined, but the ability of Bacillus sp. spores to survive for exceptionally long periods is well documented (Kennedy et al., 1994). Isolates recovered aerobically must be capable of anaerobic growth if they are to exhibit in situ activity. Of a representative subset of the deepest aerobic isolates held in the culture collection, almost all were found to be facultatively anaerobic when cultured upon nutrient agar supplemented with $0 \cdot 1 \%$ $\mathrm{KNO}_{3}$. Those isolates that failed to grow cannot be classified as obligate aerobes without further study as this medium cannot be considered universal for anaerobic organisms. Heterotrophs were isolated anaerobically with frequencies equivalent to those cultivated aerobically. It is possible that these independently obtained counts may represent the same subpopulations.

In this study, actinomycetes were only recovered to a depth of $74 \mathrm{~cm}$ (1000 years deposition), and Micromonospora sp. was the only actinomycete isolated. A further incubation period at $50^{\circ} \mathrm{C}$ failed to promote the growth of any thermoactinomycetes. This confirms previous studies which found Micromonospora sp. populations in sediments down to $1 \mathrm{~m}$ depth in Thirlmere and Windermere (both in UK; Cross, 1981). However, in addition to Micromonospora, nocardioform actinomycetes and Streptomyces spp. were isolated from both water bodies, with the latter being predominant with increasing depth (Cross \& Attwell, 1974; Johnston, 1972).

Postgate's (1984) medium B for sulphate-reducing bacteria (SRB) was modified to include both acetate and lactate as carbon sources as a means of optimizing the recovery of SRB. The deepest sample to yield culturable SRB was from $77 \mathrm{~cm}$. At this depth, sulphate is almost certainly depleted (Jørgensen, 1983). Therefore, it is unlikely that these isolates were active in situ with respect to sulphate reduction (Brandl et al., 1993). In Windermere, this can be inferred from the decreasing levels of acid-volatile sulphide below $20 \mathrm{~cm} \quad(<1 \mathrm{mg}$ $\mathrm{g}^{-1}$; Rowlatt, 1980). At the sample points analysed, no sequences were isolated by PCR that were closely related to any known SRB. Declining populations of SRB are frequently indicative of conditions more likely to favour active populations of methanogens. In fresh water, methanogenesis is responsible for the bulk of terminal metabolism under anoxic conditions (Capone \& Kiene, 1988). The nature of the post-sampling handling used in these studies made it impractical to quantify methanogens by culture. However, examination of prokaryotic communities in the deepest core samples by targeting 
$16 \mathrm{~S}$ rDNA revealed several sequences that were most likely to have been derived from methanogenic species (see below).

In the sediments of Windermere viable cells were detected by microscopy to depths of $5.8 \mathrm{~m}$, representing deposition events over 10000 years ago. The numbers of CTC-reducing cells were consistently lower than the total bacterial numbers, but, in common with published work using acridine orange/INT (2-[4-iodophenyl]-3[4-nitrophenyl]-5-phenyltetrazolium), values were usually within a single order of magnitude (Porter et al., 1995). The fact that the proportion of non-respiring bacteria in these sediments did not increase with depth implies that dead bacteria were not accumulating with depth.

To complement the use of the tetrazolium salts, CFDA was applied to the same samples to give an independent assessment of bacterial viability. While in the upper sediments CFDA and CTC counts were indistinguishable, with increasing depth the number of CFDAcleaving cells decreased in comparison to the CTCreducing populations, but CFDA-cleaving cells were still detectable in the deepest sample. The reason for this anomaly between techniques is unclear and, as is frequently the case with the analysis of heterogeneous environmental populations, data must be interpreted with caution. The protocol for the staining with CFDA differs from that of the CTC and DVC techniques in that it did not require incubation in the presence of a nutrient source. This being the case, counts of CFDA-cleaving bacteria may provide a more faithful representation of in situ metabolic activity. However, the sensitivity of these different assays can have a significant affect on interpretation. Porter et al. (1995) demonstrated that the efficiency of a range of fluorescent probes was variable for the assessment of physiological status of starved Escherichia coli. In the case of Windermere sediments, the heterogeneity of environmental samples and the variability of viability probes made their use representative of populations rather than as a total viability count.

The number of substrate-responsive bacteria (DVC) constituted approximately $90 \%$ of the total bacterial count in the surface sediments. With increasing depth, the number of substrate-responsive cells decreased, yet positive cells remained detectable in the deepest samples. In all samples, populations were observed that were metabolically active on the basis of CTC reduction yet did not demonstrate cell growth and elongation. Roszak \& Colwell (1987) compared the DVC and microautoradiographic methods and observed the same effect. It is possible that these non-responsive, yet viable cells may be unable to grow due to sublethal injury (Gurijala \& Alexander, 1988). More likely, as with the other enumeration techniques applied in this work (except AODC), the DVC is subject to bias; the carbon source used and the antibiotics applied will favour the enumeration of some species more than others (Fry, 1990). It is interesting that the numbers of substrate-responsive bacteria more closely mirror the counts of CFDA, and thereby the bacteria active in situ, than do the counts obtained by the direct CTC viability assay. Further investigation to combine the DVC with CFDA or fluorescent in situ hybridization (FISH) would be desirable to confirm any possible correlation between the activity of esterases and the ability to demonstrate growth.

The eubacterial $16 \mathrm{~S} \mathrm{rDNA}$ gene sequences isolated in this study, although limited in number, were diverse in type, being distributed throughout both the Grampositive and Gram-negative groups. However, similar sequences were observed in different levels within the core (e.g. Wineub 010 and 027). The isolation of $r r n$ genes of high homology to those of Bacillus species (which are frequently recalcitrant to lysis) suggests that the DNA extraction procedure provided a template for PCR that is broadly, but not unequivocally, representative of the bacterial community. The recovery of Gram-positive sequences reported here is commensurate with the findings of several other researchers who have demonstrated the prevalence of culturable Gram-positive organisms in sediments to depths of $500 \mathrm{~m}$ (Gehron et al., 1984; Reeves et al., 1995).

Rochelle et al. (1992) inferred the dominance of subsurface bacterial populations by species of the Proteobacteria $(80 \%)$ from pristine marine samples. Similarly, proteobacterial sequences were prevalent in Windermere sediment, with identical sequences being isolated from separate sample points down to depths of $5 \cdot 2 \mathrm{~m}$ (10000 years; e.g. Wineub 076, 117; Fig. 4). The isolation of sequences highly homologous to those of Ralstonia (formerly Pseudomonas and then Burkholderia) spp. is particularly interesting since these correlate with the reported isolation of species of the Pseudomonadaceae, identified phenotypically and genotypically, from these sediments (data not presented).

Independent isolation of sequences of novel delineation is presented in this work, corroborating novel sequences previously described by Rochelle et al. (1994) and Hales et al. (1996). The isolation of a sequence, Wineub 012 (from a depth of $4.4 \mathrm{~m}, 8000-9000$ years), of high sequence similarity, and equivalent delineation, to the clones of the JAP504 cluster as reported by Rochelle et al. (1994) from deep marine sediments, is very significant. Independent recovery from freshwater sediments implies that these sequences represent organisms from a single group with wide-ranging phenotypic properties and a wide geographical distribution.

Several archaeal sequences were recovered from a depth of $3.4 \mathrm{~m}$ (7000 years deposition) and $5.8 \mathrm{~m}$ (11000 years deposition), with one sequence common to both depths (Winarc 038, 057 and 123). Sequences were recovered that were similar to the novel clones isolated from Pennine peat by Hales et al. (1996). This was perhaps not unexpected, as this sediment environment, being permanently anoxic, was predicted to contain methanogenic species. 16S rRNA sequence identities do not guarantee species identity as determined by DNA-DNA hybridization (Fox et al., 1992), nor do they imply 
functional activity. Nevertheless, many physiologically specialized microbial groups (the methanogens among them) are phylogenetically coherent or restricted to a limited number of assemblages (Stahl et al., 1988; Stahl \& Amman, 1991). The point of delineation of the archaeal clones amongst other reference methanogenic sequences implies that their source organisms possess methanogenic properties. The description of methanogens presented in this study remains qualitative but suggests that, for this system, methanogenesis is the final important process in anaerobic mineralization, given the absence of sulphate-reducing bacteria. Future studies should focus on a quantitative approach that would allow a direct comparison with the better-studied deepsea sediments, where different processes predominate; for example, the Japan Sea, where sulphate-reduction processes were detected at depths $>500 \mathrm{~m}$ (Parkes et al., 1994).

The recovery of gene sequence information from DNA templates does not necessarily indicate in situ cellular activity. It is possible that the bacteria have lysed and naked DNA is forming the target template for PCR, or that their cells have retained structural integrity in a state of death or dormancy. However, coupled with observations on viability, culturability and direct microscopy with non-specific dyes, the gene sequence information reported here implies that the deep sediments of Windermere do contain active bacteria derived from those deposited during sedimentation events during the last Ice Age in Britain.

\section{ACKNOWLEDGEMENTS}

This work was funded by postgraduate studentships (I. M., K.L. and G.R.) from the Natural Environment Research Council. Peter Allen and Paul Hodgson (IFE) are thanked for obtaining the $6 \mathrm{~m}$ sediment cores, as is Ken Clarke for electron microscopy.

\section{REFERENCES}

Balkwill, D. L., Fredrickson, J. K. \& Thomas, J. M. (1989). Vertical and horizontal variations in the physiological diversity of the aerobic chemoheterotrophic bacterial microflora in deep Southeast coastal plain subsurface sediments. Appl Environ Microbiol 55, 1058-1065.

Balkwill, D. L., Reeves, R. H., Drake, G. R., Reeves, J. Y., Crocker, F. H., King, M. B. \& Boone, D. R. (1997). Phylogenetic characterization of bacteria in the subsurface microbial culture collection. FEMS Microbiol Rev 20, 201-216.

Benson, D., Lipman, D. J. \& Ostell, J. (1993). GenBank. Nucleic Acids Res 21, 2963-2965.

Biovin-Jahns, V., Ruimy, R., Bianchi, A., Daumas, A. \& Christen, R. (1996). Bacterial diversity in a deep-subsurface clay environment. Appl Environ Microbiol 62, 3405-3412.

Brandl, H., Hanselmann, K. W., Bachofen, R. B. \& Piccard, J. (1993). Small-scale patchiness in the chemistry and microbiology of sediments in Lake Geneva, Switzerland. J Gen Microbiol 139, 2271-2275.

Brosius, J., Palmer, J. L., Kennedy, J. P. \& Noller, H. F. (1978). Complete nucleotide sequence of a $16 \mathrm{~S}$ ribosomal RNA gene from Escherichia coli. Proc Natl Acad Sci USA 75, 4801-4805.
Capone, D. G. \& Kiene, R. P. (1988). Comparison of microbial dynamics in marine and freshwater sediments: contrasts in anaerobic carbon catabolism. Limnol Oceanogr 33, 275-749.

Chapelle, F. H. \& Lovley, D. R. (1990). Rates of microbial metabolism in deep costal plain aquifers. Appl Environ Microbiol 56, 1865-1874.

Close, T. J. \& Rodriguez, R. L. (1982). Construction and characterisation of the choramphenicol-resistance gene cartridge: a new approach to the transcriptional mapping of extrachromosomal elements. Gene 20, 305-316.

Collins, V. G. (1977). Methods in sediment microbiology. Adv Aquat Microbiol 1, 219-272.

Cragg, B. A., Parkes, R. J., Fry, J. C., Herbert, R. A., Wimpenny, J.W. T. \& Getliff, J. M. (1990). Bacterial biomass and activity profiles within deep sediment layers. Proc ODP Sci Results 112, 607-619.

Cragg, B. A., Harvey, S. M., Fry, J. C., Herbert, R. A. \& Parkes, R. J. (1992). Bacterial biomass and activity in the deep sediment layers of the Japan Sea, Hole 798B. Proc ODP Sci Results 127/128, 761-776.

Cross, T. (1981). Aquatic actinomycetes: a critical survey of the occurrence, growth and role of actinomycetes in aquatic habitats. J Appl Bacteriol 50, 397-423.

Cross, T. \& Atwell, R. W. (1974). Recovery of viable thermoactinomycete endospores from deep mud cores. In Spore Research 1973, pp. 11-20. Edited by A. N. Barker, G. W. Gould \& J. Wolf. London: Academic Press.

Devereux, J., Haeberli, P. \& Smithies, O. (1984). A comprehensive set of sequence-analysis programs for the VAX. Nucleic Acids Res 12, 387-395.

Diaper, J. P. \& Edwards, C. (1994). The use of fluorogenic esters to detect viable bacteria by flow cytometry. J Appl Bacteriol 77, 221-228.

Edwards, U., Rogall, T., Blöcker, H., Emde, M. \& Böttger, E. C. (1989). Isolation and direct complete nucleotide determination of entire genes. Characterisation of a gene coding for $16 \mathrm{~S}$ ribosomal RNA. Nucleic Acids Res 17, 7843-7853.

Ekendahl, S. \& Pedersen, K. (1994). Carbon transformation by attached bacterial populations in granite groundwaters from deep crystalline bedrock of the Stripa research mine. Microbiology 140, 1565-1573.

Elliot, R. J. \& Porter, A. G. (1971). A rapid cadmium reduction method for the determination of nitrite in bacon and curing brines. Analyst 96, 522 .

Embley, T. M., Finlay, B. J., Thomas, R. H. \& Dyal, P. L. (1992). The use of rRNA sequences and fluorescent probes to investigate the phylogenetic positions of the anaerobic ciliate Metopus palaeformis and its archaeobacterial endosymbiont. J Gen Microbiol 138, 1479-1487.

Felsenstein, J. (1993). PHYLIP (Phylogeny Inference Package) version 3.5C. Seattle: Department of Genetics, University of Washington.

Fox, G. E., Wisotzkey, J. D. \& Jurtshuk, P. (1992). How close is close: $16 \mathrm{~S}$ rRNA sequence identity may not be sufficient to guarantee species identity. Int J Syst Bacteriol 42, 166-170.

Fredrickson, J. K. \& Onstott, T. C. (1996). Microbes deep inside the Earth. Sci Am 275, 42-47.

Fredrickson, J. K., Balkwill, D. L., Zachara, J. M., Shu-Mei, W. L., Brockman, F. J. \& Simmons, M. A. (1991). Physiological diversity and distributions of heterotrophic bacteria in deep Cretaceous sediments of the Atlantic coastal plain. Appl Environ Microbiol $57,402-411$. 
Fry, J. C. (1990). Direct methods and biomass estimation. Methods Microbiol 22, 41-85.

Fry, J. C. (1993). One-way analysis of variance. In Biological Data Analysis: a Practical Approach. Edited by J. C. Fry. Oxford: IRL Press.

Gehron, M. J., Davis, J. D., Smith, G. A. \& White, D. C. (1984). Determination of the Gram-positive bacterial content of soils and sediments by analysis of teichoic acid components. J Microbiol Methods 2, 165-176.

Getliff, J. M., Fry, J. C., Cragg, B. A. \& Parkes, R. J. (1992). The potential for bacterial growth in deep sediment layers of the Japan Sea, hole 798B - leg 128. Proc ODP Sci Results 127/128, $755-760$

Gurijala, K. R. \& Alexander, M. (1988). Explanation for the decline of bacteria introduced into lake water. Microb Ecol 20, 231-244.

Hales, B. A., Edwards, C., Ritchie, D. A., Hall, G., Pickup, R. W. \& Saunders, J. R. (1996). Isolation and identification of methanogen DNA from blanket bog peat using PCR amplification and DNA sequence analysis. Appl Environ Microbiol 62, 668-675.

Halvorsen, H. O. \& Zeigler, N. R. (1933). Estimation of bacterial numbers by the limiting dilution method. J Bacteriol 25, 101-121. Haworth, E. Y. (1985). The highly nervous system of the English Lakes: aquatic ecosystem sensitivity to external changes, as demonstrated by diatoms. Freshwater Biol Assoc Annu Rep 53, 60-79.

Hazen, T. C., Jimenez, L., Lopez de Victoria, G. \& Fliermans, C. B. (1991). Comparison of bacteria from deep subsurface sediment and adjacent groundwater. Microb Ecol 22, 293-304.

Horsley, R. W. (1979). The heterotrophic, nitrate-reducing bacterial flora of Grasmere, English Lake District. J Appl Bacteriol 46, 507-520.

Jarsch, M. \& Böck, A. (1985). Sequence of the 16 S ribosomal RNA gene from Methanococcus vannielii. Syst Appl Microbiol 6, 54-59.

Johnston, D. W. (1972). Actinomycetes in aquatic habitats. $\mathrm{PhD}$ thesis, University of Bradford.

Jones, J. G. (1982). Activities of aerobic and anaerobic bacteria in lake sediments and their effect on the water column. In Sediment Microbiology (Special Publication of the Society for General Microbiology no. 7), pp. 107-145. London: Academic Press.

Jones, J. G. (1985). Microbes and microbial processes in sediments. Philos Trans R Soc Lond A315, 3-17.

Jones, J. G. \& Simon, B. M. (1981). Differences in microbial decomposition processes in profundal and littoral lake sediments, with particular reference to the nitrogen cycle. J Gen Microbiol 123, 297-312.

Jones, J. G. \& Simon, B. M. (1984). The presence and activity of Desulfotomaculum spp. in sulfate-limited freshwater sediments. FEMS Microbiol Lett 21, 47-50.

Jones, J. G., Simon, B. M. \& Gardener, S. (1982). Factors affecting methanogenesis and associated anaerobic processes in the sediments of a stratified eutrophic lake. J Gen Microbiol 128, 1-11.

Jørgensen, B. B. (1983). The microbial sulphur cycle. In Microbial Geochemistry, pp. 91-124. Edited by W. E. Krumbein. Oxford: Blackwell Scientific Publications.

Jukes, T. H. \& Cantor, C. R. (1969). Evolution of protein molecules. In Mammalian Protein Metabolism III, pp. 21-132. Edited by H. N. Munro. New York: Academic Press.

Kennedy, M. J., Reader, S. L. \& Swiercznski, L. M. (1994). Preservation records of microorganisms: evidence of the tenacity of life. Microbiology 140, 2513-2529.
Kogure, K., Simidu, U., Taga, N. \& Colwell, R. R. (1987). Correlation of direct viable counts with heterotrophic activity of marine bacteria. Appl Environ Microbiol 53, 2332-2337.

Krumholz, L. R., McKinley, J.P., Ulrich, F. A. \& Suflita, J. M. (1997). Confined subsurface microbial communities in Cretaceous rock. Nature 386, 64-66.

Larsen, N., Olsen, G. J., Maidak, B. L., McCaughtey, M. J., Overbeek, R., Macke, T. J., Marsh, T. L. \& Woese, C. R. (1993). The Ribosomal Database Project. Nucleic Acid Res 21, 3021-3023.

Lovley, D. R. \& Chapelle, F. H. (1995). Deep subsurface microbial processes. Rev Geophys 33, 365-381.

Macan, T. T. (1970). Biological Studies of the English Lakes. London: Longman.

Mackereth, F. J. H. (1958). A portable core sampler for lake deposits. Limnol Oceanogr 3, 181-191.

Nilsson, M. \& Renberg, I. (1990). Viable endospores of Thermoactinomyces vulgaris in lake sediments as indicators of agricultural history. Appl Environ Microbiol 56, 2025-2028.

Ogram, A., Sun, W., Brockman, F. J. \& Fredrickson, J. K. (1995). Isolation and characterisation of RNA from low-biomass deepsubsurface sediments Appl Environ Microbiol 61, 763-768.

Ohnstad, F. R. \& Jones, J. G. (1982). The Jenkin Surface Mud Sampler. User Manual. Freshwater Biol Assoc Occas Pub no. 15.

Parkes, R. J., Cragg, B. A., Bale, S. J., Getliff, J. M., Goodman, K., Rochelle, P. A., Fry, J. C., Weightman, A. J. \& Harvey, S. M. (1994). Deep bacterial biosphere in Pacific Ocean sediments. Nature 371, 410-413.

Pennington, W. (1943). Lake sediments: the bottom deposits of the north basin of Windermere, with special reference to the diatom succession. New Phytol 42, 1-27.

Pennington, W. (1973). The recent sediments of Windermere. Freshwater Biol 3, 363-382.

Pennington, W. (1981). Records of a lake's life in time: the sediments. Hydrobiologia 79, 197-219.

Pennington, W. (1991). Paleolimnology in the English lakes some questions and answers over fifty years. Hydrobiologia 214, $9-24$.

Phelps, T. J., Murphy, E. M., Pfiffner, S. M. \& White, D. C. (1994). Comparison between geochemical and biological estimates of subsurface microbial activities. Microb Ecol 28, 335-349.

Porter, J., Diaper, J., Edwards, C. \& Pickup, R. W. (1995). Direct measurements of natural planktonic bacterial community viability by flow cytometry. Appl Environ Microbiol 61, 2783-2786.

Postgate, J. R. (1984). The Sulphate Reducing Bacteria, 2nd edn. Cambridge: Cambridge University Press.

Reasoner, D. J. \& Geldreich, E. E. (1985). A new medium for the enumeration and subculture of bacteria from potable water. Appl Environ Microbiol 49, 1-7.

Reeves, R. H., Reeves, J. Y. \& Balkwill, D. L. (1995). Strategies for phylogenetic characterisation of subsurface bacteria. J Microbiol Methods 21, 235-251.

Rochelle, P. A., Fry, J. C., Parkes, R. J. \& Weightman, A. J. (1992). DNA extraction for $16 \mathrm{~S}$ rRNA gene analysis to determine genetic diversity in deep sediment communities. FEMS Microbiol Lett 100, 59-66.

Rochelle, P. A., Cragg, B. A., Fry, J. C., Parkes, R. J. \& Weightman, A. J. (1994). Effect of sample handling on estimation of bacterial diversity in marine sediments by $16 \mathrm{~S}$ rRNA gene sequence analysis. FEMS Microbiol Ecol 15, 215-226.

Rodriguez, G. G., Phipps, D., Ishiguro, K. \& Ridgeway, H. F. 
(1992). Use of a fluorescent redox probe for direct visualisation of actively respiring bacteria. Appl Environ Microbiol 58, 18011808.

Roszak, D. B. \& Colwell, R. R. (1987). Metabolic activity of bacterial cells enumerated by direct viable count. Appl Environ Microbiol 53, 2889-2983.

Rothfuss, F., Bender, M. \& Conrad, R. (1997). Survival and activity of bacteria in a deep, aged lake sediment (Lake Constance). Microb Ecol 33, 69-77.

Rowbotham, T. J. \& Cross, T. (1977). Ecology of Rhodococcus coprophilus and associated actinomycetes in freshwater and agricultural habitats. J Gen Microbiol 100, 231-241.

Rowlatt, S. M. (1980). Geochemical studies of recent lake sediments from Cumbria, England. PhD thesis, University of Liverpool.

Saitou, N. \& Nei, M. (1987). The neighbour joining method: a new method for constructing phylogenetic trees. Mol Biol Evol 4, 406-425.

Sambrook, J., Fritsch, E. F. \& Maniatis, T. (1989). Molecular Cloning: a Laboratory Manual, 2nd edn. Cold Spring Harbor NY: Cold Spring Harbor Laboratory.
Selenska, S. \& Klingmuller, W. (1991). DNA recovery and direct detection of Tn5 sequences from soil. Lett Appl Microbiol 13, 21-24.

Smalla, K., Cresswell, N., Mendoca-Hagler, L. C., Walters, A. \& van Elsas, J. D. (1993). Rapid DNA extraction protocol from soil for polymerase chain reaction-mediated amplification. J Appl Bacteriol 74, 78-85.

Stahl, D. A. \& Amman, R. (1991). Development and application of nucleic acid probes in bacterial systematics. In Nucleic Acid Techniques in Bacterial Systematics, pp. 205-248. Edited by E. Stackebrandt \& M. Goodfellow. Chichester: Wiley.

Stahl, D. A., Flesher, H. R., Mansfield, H. R. \& Montgomery, L. (1988). Use of phylogenetically based hybridisation probes for studies of ruminal microbial ecology. Appl Environ Microbiol 54, 1079-1084.

Wellsbury, P., Goodman, K., Barth, T., Cragg, B. A., Barnes, S. P. \& Parkes, R. J. (1997). Deep marine biosphere fuelled by increasing organic matter availability during burial and heating. Nature $\mathbf{3 8 8}$, $573-576$.

Received 12 February 1998; revised 12 May 1998; accepted 2 June 1998. 